\title{
THE TRANSFORMATION OF SCIENCE COMMUNICATION IN VUCA ERA: Study of Media Startups Kok Bisa in Indonesia
}

\author{
Syora Alya Eka Putri and Ricardi S Adnan \\ Department of Sociology \\ Universitas Indonesia, Depok, Indonesia \\ Corresponding Author Email: alyadjunasig@gmail.com
}

\begin{abstract}
This study analyzes the transformation of science communication conducted by media startups in the VUCA era in Indonesia. In the information age, especially during the COVID-I9 pandemic, people are increasingly dependent on educational needs. Nevertheless, there are challenges of information explosion that are too dynamic and less effective. As a result, media startups have implemented science communication innovations to open public access to science. Previous studies have acknowledged science communication models using visual literacy approaches and using narrative explanations. Therefore, the model faces significant challenges such as information uncertainty, establishing a science communication ecosystem, and ambiguity due to cultural change. Employing qualitative content analysis methods, this article found that media startups face the biggest challenges in developing science communication. On the other hand, the VUCA era can be a driving tool for media startups to conduct adaptive social transformation in the field of science communication.
\end{abstract}

Keywords: VUCA, science communication, media startups, information, social transformation

\begin{abstract}
Abstrak
Penelitian ini menganalisis transformasi komunikasi sains yang dilakukan oleh startup media dalam era VUCA di Indonesia. Dalam information age, terlebih saat masa pandemi COVID-I9, masyarakat semakin bergantung pada informasi untuk kebutuhan edukasi. Namun, terdapat tantangan information explosion yang terlalu dinamis dan kurang efektif. Alhasil, inovasi komunikasi sains dilakukan oleh startup media untuk membuka akses publik ke ilmu pengetahuan. Studi sebelumnya melihat model komunikasi sains menggunakan pendekatan literasi visual dan menggunakan penjelasan naratif. Namun, model tersebut menghadapi tantangan besar seperti ketidakpastian informasi, belum terbentuknya ekosistem komunikasi sains, dan ambiguitas akibat perubahan kultur. Menggunakan metode qualitative content analysis, artikel ini menemukan bahwa adanya tantangan terbesar yang dihadapi oleh startup media dalam mengembangkan komunikasi sains. Namun disisi lain, justru era VUCA dapat menjadi sarana pendorong bagi startup media untuk melakukan transformasi sosial yang adaptif dalam bidang komunikasi sains.
\end{abstract}

Kata kunci: VUCA, komunikasi sains, startup media, informasi, transformasi sosial 


\section{INTRODUCTION}

In the information age, there is a development of communication technology that affects society's changing patterns towards information use. Initially, information is a necessity to increase knowledge. Then, slowly, people use the information to create innovations and build network societies (Castell, 20Io; Mansell, 20Io).

As websites and social media develop, people actively seek information in their daily lives, besides seeking entertainment and social interaction (Kim, Shin, and He, 2013; Bilgihan, Peng, and Kandampully, 20I4; Hamid et al., 2016). The search for information conducted by individuals is subject to the availability of authorized access to information or under education cue, group segmentation/representation, and the effects of online engagement (Cao et al., 20I6; Spezi, 2or6; Segev and Sharon, 20I7; Michalovich and Herskhovitz, 2020).

Nevertheless, in times of crisis during the COVID-I9 pandemic, people's behavior in seeking information has also changed to be more preventive using official information because of information overload and fake news (Liu, 2020; Apuke and Omar, 202I; Soroya et al.,202I).

In Indonesia, one medium used by the public to find information is Youtube. From We Are Social data (2020), about $88 \%$ of people use Youtube, which is still predominantly used for entertainment and music. The media can also be a source of information and learning that is deliverable to the community (Jung and Lee, 2015; Chintalapati and Daruri, 2016; Welbourne and Grant, 20I6).

In the situation of the COVID-I9 pandemic, there is an increasing need for educational content in Indonesia as learning activities move into the digital world. However, according to the Ministry of Education and Culture, the amount of educational content was relatively minimal compared to entertainment and music content. Therefore, educational content creators have an essential role in increasing Indonesia's educational content ( $\mathrm{Zu}-$ lfikar, 2020; Sandi, 2020; Lawi, 2020; Princess, 2020). The strategy can improve educational content in social media is interactive for the community through science communication (Brossard, 2009; Stilgoe, Lock and Wilsdon, 20I4; Zolkepli and Kamarulzaman, 2015; Agostino and Arnaboldi, 2or6; Lopez and Sanchez, 20I8).

Currently, the development of science communication through educational content in Indonesia is conducted by several media startups such as 'Kok Bisa,' 'Satu Persen,' 'Ayo Mikir,' 'Hujan Tanda Tanya,' 'Zenius Education,' 'Quipper,' 'Sains Bro' and so on.

One of the media startups that have the initiation of multiplying educational content during the COVID-I9 pandemic is Kok Bisa, through educational academies in collaboration with the Ministry of Education and Culture, Youtube Learning, and Indonesian Institute of Science (LIPI) (Kasih, 2020; Antara Editor, 2020; Editor of The Jakarta Post, 2020). Media startups Kok Bisa has been established in 2015, starting now over five years ago. The startups means it has passed the exit vulnerability phase because almost $50 \%$ of new businesses failed before five years of operation (Teece, Peteraf, and Leih, 20I6; Picken, 20I7; Perry, Rahim, and Davis, 20I8).

Kok Bisa is one of the educational channels with the largest number of followers in Indonesia, with 2.5 million subscribers on Youtube. Innovations made by Kok Bisa have received various awards such as Inspirational Stories by Google for Indonesia in 2018, best educational video award by Popcon Asia in 2017, Youtube Ambassador and Youtube Creator for Change. Prior to the innovation made by Kok Bisa, interesting science-based educational content and easy to understand by the public. It was reasonably minimal in Indonesia when compared to the amount of harmful and hoax content. Content created using motion graphic models and storytelling narratives. Then, Kok Bisa chose the Youtube platform to be an alternative educational content provider in Indonesia (Jeko, 2015; Duhita, 20I7; Kholifah, 20I8).

The innovation of science communication conducted by media startup Kok Bisa is in line with previous studies through visual literacy and narrative storytelling. The use of visual 
literacy can attract public attention according to public imaginary (Bucchi and Saracino, 2016; Pearce et al., 2018; Fox, Nakhata, and Deitz, 20I9; Wilke and Hill, 2019). Narrative storytelling also makes educational information more engaging with the public (Padian, 2018; Finkler and Leon, 2019; Yang and Hobbs, 2020). Nevertheless, the development of science communication innovation in Indonesia faces challenges, i.e information explosion that tends to be less effective (Firdausi, 2018; Wicaksono, 2018).

Therefore, as for other complex and significant uncertain challenges such as no control on the extreme circulation of information (Lievrouw, 20I0; Macnamara and Zelfass, 20I2; Dwivedi et al., 2018; Umeozor, 2019); the uncertainty of information (Guenther et al., 20I9); the establishment of ecosystems and inter-party collaboration in science communication (Clausen et al., 2013; Peters, 2013; Ganon and Sabus, 20I4; Dudo, 2015; Salmon, Prescley and Goven, 20I5; Rundjan, 20I8); and ambiguity because it is less relevant to traditional norms and local cultures (Plantin et al., 2018; Davies et al., 2019; Wang et al., 2019). From that case, there is a further question: how can the innovation of science communication by media startups develop in the era of VUCA?

The development of science communication innovations conducted by media startups is in line with YouTube's popularity for interactive sources of information for the public (Hua, 2015; Ariel and Avidar, 2015; Rapp et al., 20I6; Almobarazz, 20I8; Moghavvemi et al., 2018). These innovations have opened up opportunities for people to access more valid information and engage with science (Allgaier et al., 20I3; Davies and Hara, 20I7; Hecker et al., 2018; Bucchi, 2019; Jones-Jang, 2020).

Nonetheless, media startups also play a role in curating content, shaping critical thinking strategies, and contextualizing information quality (Noonan et al., 20I7; Kandalgaonkar, 2015; Tenkasi, 2018). Therefore, transforming science communication in the VUCA era is needed. Based on the challenges faced, the VUCA era can be a means to transform science communication conducted by organizations/companies, such as media startups.
The four disruptive challenges such as volatility, uncertainty, complexity, and ambiguity can drive an adaptive transformation process and become the basis for producing realistic innovations.

This research aims to explain VUCA conditions faced by media startups and the transformation of science communication conducted by media startups in social media in Indonesia. Therefore, this study can be compiled into the research questions: [I] how the condition of VUCA faced by media startups in science communication and [2] how the transformation of science communication by media startups in the era of VUCA.

\section{THEORETICAL UNDERPINNINGS}

\section{VUCA World}

The VUCA era is a situation of four challenges of the modern era: vulnerable, uncertain, complex, and ambiguous. These conditions can be identified in the organizational environment, which can then be developed as a cornerstone of strategizing (Bennett and Lemoine, 20I4). Then, the VUCA era can be an innovation developed by organizations/companies to form a new culture of improving public education literacy in order to be economically productive (Guedes, n.d; Bernstein, 20I4; Shliakhovchuk, 20I9).

To address these challenges, there are strategies faced by leaders in globalization asshown in table I.: 
Table I. VUCA and Strategies

\begin{tabular}{|c|c|}
\hline VUCA & Strategies \\
\hline $\begin{array}{l}\text { Volatile: Situations where the environment is } \\
\text { very unstable and volatile changes often occur, } \\
\text { even unpredictable. }\end{array}$ & $\begin{array}{l}\text { Agility: The strategy for creates the potential to } \\
\text { see the possibilities in the future. }\end{array}$ \\
\hline $\begin{array}{l}\text { Uncertainty: The situation of limited } \\
\text { knowledge or information because it sees a } \\
\text { significant change. }\end{array}$ & $\begin{array}{l}\text { Information: Information is organized based } \\
\text { on data and also considers a new perspective. }\end{array}$ \\
\hline $\begin{array}{l}\text { Complexity: Situations involving multiple } \\
\text { connections are intertwined with very diverse } \\
\text { forms, resulting in a more complicated process } \\
\text { of elaboration and procedures. }\end{array}$ & $\begin{array}{l}\text { Restructuring: The process simplifies the } \\
\text { flow and process in the existing network } \\
\text { environment to be more efficient and effective. }\end{array}$ \\
\hline $\begin{array}{l}\text { Ambiguity: A situation of limited knowledge } \\
\text { that looks at the causes and impacts is quite } \\
\text { difficult to understand because there is no } \\
\text { precedent in making predictions. }\end{array}$ & $\begin{array}{l}\text { Experimentation: Experiments are conducted } \\
\text { to be able to find out what strategies leaders can } \\
\text { take. }\end{array}$ \\
\hline
\end{tabular}

Source: Bennett and Lemoine, 2014

\section{Science Communication}

Science communication could make science easier to understand by the public. It can be done by increasing awareness, understanding, literacy, and the community's scientific culture to become more interested in science (Burns, O'Connor, and Stocklmayer, 2003). Nowadays, science communication can become popular by utilizing social media. Because it presents interactive content and can help improve people's literacy towards science (Bucchi and Saracino, 2016).

The science communication model used today adopts marketing communication and science journalism. The form of marketing communication used is storytelling, where this method can reach the wider community (Dahlstorm, 20I4). Furthermore, the form of science journalism is so attached to society's cultural context, experiences, and emotions. It makes contextualization realistic in producing information related to science (Wilcox, 2003; Davies et al., 20I9). The combination of these two forms helps science communication run effectively.

\section{Social Transformation}

Nevertheless, innovation in one of these areas also resulted in social transformation. It would lead to significant changes, changing socio-economic patterns, and restructuring actors due to technological disruption (Castels, 20or; Kenney, Rouvinen, and Zysman, 20I5). To that end, actor capabilities play an essential role in shaping more adaptive social transformations (Barnes et al., 20I7; Khan, 2019).

The three drivers that can be utilized by actors in social transformation in this study such as [I] make the social platform as a catalyst and accelerator institutionalization of social change (Letaifa, Edvardsson, and Tronvoll, 2016), [2] science as a driver of human activity to organize social order (Popova, Moiseenko, and Beavitt, 20I7), and [3] social initiatives built by actors in improving relationship building and sharing knowledge (Barkin and Sanchez, 2020).

\section{METHODS}

This research employed a qualitative content analysis method, which is a method for describing meaning in qualitative material with a set of coding frames (Schreier, 20I2). The method is visualized with the word cloud to facilitate analysis and readability of the depiction of phenomena in studies (DePaolo and Wilkinson, 20I4). The application is used for visualization in Tableau. Furthermore, the phenomenon of this study is the condition 
of VUCA and the strategy carried out by media startup Kok Bisa in the field of science communication. Therefore, the data sources which were employed for analysis were transcripts of interviews of Io key informants, webinar videos, and news articles spanning the years 2015-202I. This study focused on puts the organizational analysis unit, specifically the media startup Kok Bisa, as the subject because it has been established five years ago and it is still operating until now. Moreover, it has millions of followers on its social media.

The procedures are: [I] determining research questions, [2] choosing the materials used for interview transcripts, webinar videos, and news articles, [3] building coding frames based on the main theories of volatility, uncertainty, complexity, and ambiguity along with each strategy of agility, information, restructuring, and experimentation, [4] using a unit of coding with several keywords following the coding frame, and [5] analyzing and interpreting the findings. To ensure data validation, this study applied data source triangulation by looking at multiple sources. The limitation is science communication in Indonesia that is not familiar, and the privacy policy constrains the limitations of data retrieval, thus specific information is limited. Delimitation in this study is the data used is quite complex, therefore the adjustment of the word means the same.

\section{SCIENCE COMMUNICATION IN THE VUCA ERA AND ITS TRANSFORMATION PROCESS}

Media startups Kok Bisa popularizes science in Indonesia, inseparable from various challenges in the modern era, i.e volatile, uncertainty, complexity, and ambiguity. In VUCA theory, every vulnerable, uncertain, complex, and ambiguous condition has its way out as a step to turn the problem into a solution.

These strategies include agility, information, restructuring, and experimentation. These four strategies can lead VUCA to a more adaptive social transformation process, especially in science communication conducted by media startups. Besides, social transformation can be encouraged through the utilization of social platforms, knowing, and conducting several initiations performed by actors.

\section{Volatile}

The first challenge is volatile. The condition of the vulnerability relates to aspects of changes that occur very dynamic and volatile. The word cloud shows three significant keywords, such as COVID-I9, algorithms, and changes in learning to digital media.

Figure I. Word Cloud of Volatile

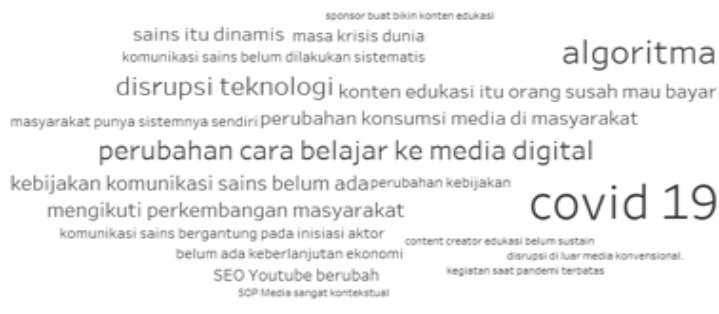

The COVID-I9 pandemic became the first significant keyword that made science communication conditions in general vulnerable, including those done by media startup Kok Bisa. In this pandemic, there has been a disruption that makes changes in learning methods and changes in consumption patterns to digital media. Nevertheless, unfortunately, educational content in digital media such as Youtube is not so much.

Since the science communication policy itself does not exist and science communication has not been done systematically, this makes science communication conducted by media startups would be vulnerable. It is caused by the lack of content and no systematic policies. The condition of the COVID-I9 pandemic also depends on the initiation done by actors. Media startups Kok Bisa is one of the drivers to create educational content in Indonesia. It can utilize this rapid and unexpected change to create educational content in Indonesia. Quoting from an interview with Kok Bisa founder, during the beginning of COVID-I9, media startups Kok Bisa had difficulty adapting because the number of projects worked on suddenly stopped.

On the other hand, the need for sci- 
ence-based educational content is increasing as a support for people's digital learning. This shows a change in the use of educational content on Youtube as an alternative to shifting into the primary source of information. Nonetheless, the educational content provider is still minimal; hence it will encourage the initiation of actors to reproduce educational content to meet these needs.

In addition to COVID-I9, another keyword in factors of volatility is algorithms. The algorithm referred to here is the platform used by media startups, Youtube as the primary channel to disseminate content to the public. The role of algorithms in Youtube becomes the main navigation for the audience to find video material and other information relevant to their interests. If the content is unpopular and liked by the audience, then the platform will not provide similar content recommendations to the audience. This is an obstacle because the algorithm does not optimize academic goals but rather for advertising revenue (Derakhshan et al., 20I9; Fyfield, Henderson, and Phillips, 2020).

In other words, the algorithm can also be a factor that supports media startups to distribute educational content and create content appeals to the audience. The problem was also an obstacle experienced by media startups Kok Bisa, because the audience gets content through recommendations from the Youtube platform. The science content produced by Kok Bisa is not popular enough compared to other content such as entertainment. As a result, science content tends to be challenging to find by audiences who consume content based on Youtube platform recommendations.

Furthermore, the third keyword shows volatility is the change in the way people learn digital media as a form of community adaptation during the COVID-I9 pandemic. The change in society occurs dynamically following technological developments and natural conditions such as COVID-I9. Now, people learn to make use of digital media available on Youtube.

Therefore, the circulation of misleading and low-quality information is spread quickly and quite troubling for the community. As a result, content producers' trustworthiness can also prevent such uncontrollable circulation (Kocygit, Akaltun, and Sahin, 2020). As an experienced media, Kok Bisa media startup can be a source that can be used as a learning medium for people on Youtube.

Nonetheless, the content that Kok Bisa has produced is a common question and based on curiosity. Because of this change, media startup Kok Bisa can create content that fits the growing issue and corresponds to learning in schools. Up to now, the Kok Bisa Explains series on the introduction of sciences such as Mathematics, Physics, Chemistry, Economics, and others can meet students' needs to understand the school lessons.

On the other hand, there is not yet available content and has not been fulfilled by other content creators. The vulnerable condition is seen when the public hangs information produced by the media. However, the media is also vulnerable to follow the changes that exist in society.

Figure 2. Word Cloud of Agility

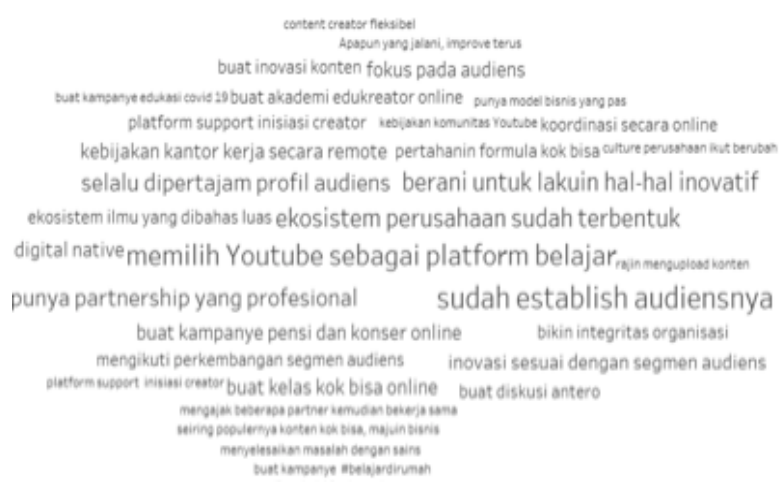

The strategy to overcome volatile conditions is to build agility. Some of the ways that media startups Kok Bisa, which is shown by the most extensive keywords in the word cloud such as [I] the enterprise ecosystem has been formed, [2] always sharpen the profile of its audience, therefore the educated target becomes clear, [3] do some innovative things. Innovative things to do include making Kok Bisa classes online, developing educational and learning content through Youtube, COVID-I9 
education campaigns, creating Antero discussions, creating online concert, and campaigning \#BelajarDiRumah.

The ecosystem of companies that have been formed, plus having several professional partners make media startups Kok Bisa can survive in vulnerable conditions such as the COVID-I9 pandemic. Currently, Kok Bisa is under a major media company, Tempo.

Then, since it has been established for five years, Kok Bisa also has a professional partnership system to network with other central agencies. The ecosystem is strengthening with the community as its audience is more loyal to consume the content created by Kok Bisa. This is shown by the extensive engagement on each post-Kok Bisa both on Youtube and Instagram. Also, Kok Bisa has the initiation to develop several events online by adjusting its audience's needs and the COVID-I9 situation. For example, curating educational content from several content creators to fill in learning activities at home, providing training on creating interesting educational content, discussing the mutation of the COVID-I9 virus online, and creating online concerts.

The initiation is supported and involves Youtube as a platform and related agencies such as the Ministry of Education and Culture and the Indonesian Institute of Sciences (LIPI). Internally, Kok Bisa also has an adequate capability as a digital native to adapt to utilizing platforms and other technologies. From some of these things, Kok Bisa, with its agility, can do social transformation, because it knows digital natives, utilizes the platform, and has several initiations involving several stakeholders, both large agencies and the community as its audience.

\section{Uncertainty}

Furthermore, another challenge faced by media startups Kok Bisa is uncertainty. This uncertainty is an unpredictable event due to rapid and uncontrollable changes, making the situation uncertain. The keywords in the uncertainty are quite a lot from the previous conditions. In a word cloud, significant keywords are shown with the most prominent writing: momentum, information overload, no expert as an information gatekeeper, and actors still in its circle.

In general, there is a certain momentum, such as the COVID-I9 pandemic, changes in government policy become the keywords that become the most prominent factor causing the situation to become a crossroads. In this case, the public needs official information generated by the media.

Figure 3. Word Cloud of Uncertainty

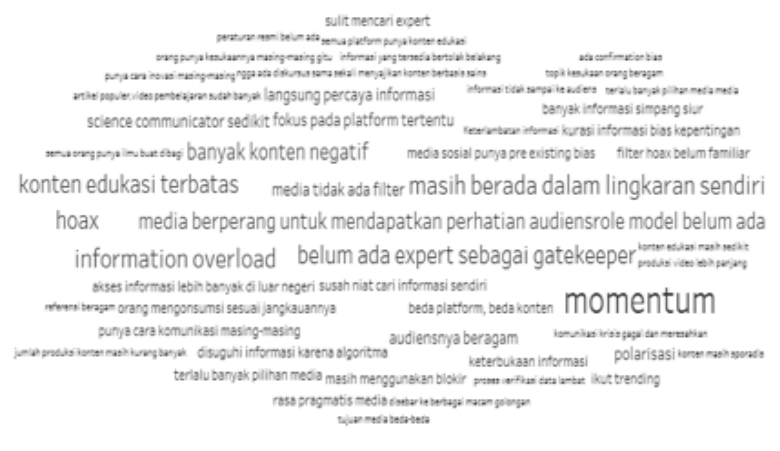

Nonetheless, amid information disclosure, anyone who comes from a different circle other than the mass media also exposes his thoughts. Then, the information circulating becomes overloaded. As a result, access to crucial information needed amid momentum is also challenging to find.

Another challenge in uncertainty is the absence of experts who become gatekeepers. Experts in each scientific field must definitely provide validation for the variety of information circulating in the lay community. Nevertheless, the number of experts is limited, especially in justifying according to expertise, making accurate information difficult to recognize amid the many hoax news circulating in the community. In this case, experts can also act as science communicators.

Unfortunately, the number of science communicators is also still limited. The impact of educational content is also limited. The position of an expert is quite vital as an information curator because the media platform does not have a qualified filter. It is also a challenge for media startups, because in some 
instances, it requires the presence of someone experienced in their field to justify information so as not to dissolve in this confusion.

Next, information overload also color the situation becomes increasingly uncertain. Social media platforms, such as Youtube and Instagram, where users can make information freely, gives rise to its polemic because of the absence of gatekeepers. As a result, people who are waiting for official information can quickly trust the information's truth because of the number of people who have an opinion on momentum rather than to clarify something. In this case, the media startup Kok Bisa can be a reference by the public; unfortunately, because the amount of information is overwhelming, hence the existence of this credible source requires a more in-depth search process. The search is done due to the overloaded information seems often to drown out credible information that media startups have produced. The credible information is also difficult to penetrate a wide variety of audiences that have their circle. Similarly, the producers who have credible information also have limitations because it is still in their respective circles. In other words, the situation adds to the long list of challenges amidst overloaded information.

Figure 4. Word Cloud of Information

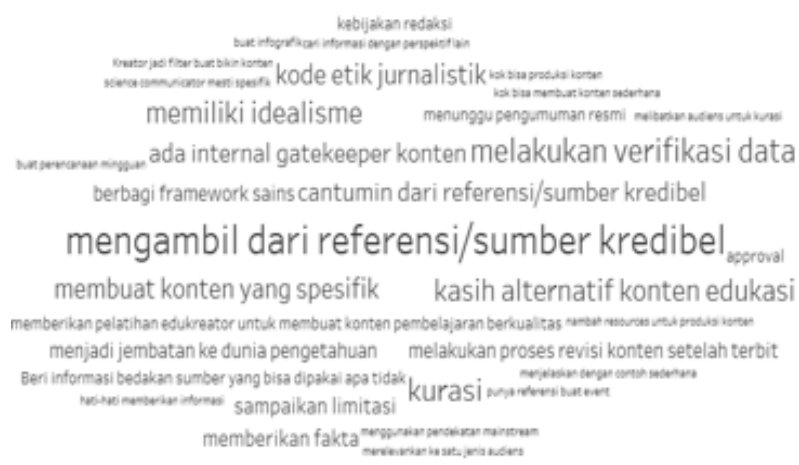

Strategies to overcome uncertainty conditions are information. This purpose refers to credible and accurate data. In the word cloud, some main keywords describe information, such as retrieving data from credible sources or references, verifying data and curating, having an internal gatekeeper, referring to the journalistic code of conduct, and listing credible sources on each content served.

Through credible sources, the information generated by media startups Kok Bisa remains accurate. That accuracy is also supported by curation, data verification, and gatekeeper information. Gatekeeper information comes from internal organizations only through the editor-in-chief. Guidelines used to maintain the validity of information amid uncertainty, i.e the code of journalistic ethics. Nevertheless, the process is always slower than fastpaced momentum. Hence, this speed will always be an inevitable problem.

Information strategy relies on an actor's ability to select a credible source and initiate an actor. The strategy applies to get its audience to distinguish whether or not a credible source can be differentiated. In the platform itself, there are several filters. Yet, it is not as accurate if the actor did it. The actor's effort is to include a credible reference link in the description field. Thus, the audience can verify itself by clicking on the given link.

\section{Complexity}

Unfinished with the conditions of uncertainty, the challenges faced become increasingly complex. The complexity refers to the complicated relationship between the actors. One of the conditions of uncertainty that leads to the complexity of relationships with each actor in its scope. There are some of the most prominent keywords in a word cloud that have interests, bureaucracy, and rigid conventional systems.

The first prominent keyword in complexity is that each actor has different interests. Diversity of interests makes the collaboration process also hampered. In general, especially in science communication, every actor has different interests. The actors are researchers, journalists, and governments.

These interests are different because they refer to different organizational focuses. Therefore, it takes an institution that becomes a bridge to accommodate these differences of interests. Nevertheless, there are no connectors yet also become a keyword that describes 
complexity conditions. This shows that media startups Kok Bisa can be a hub that connects several stakeholders such as the government, research institutions, and the private sector. Only these diverse interests make it difficult for the bridge stakeholders to make it simpler.

Figure 5. Word Cloud of Complexity

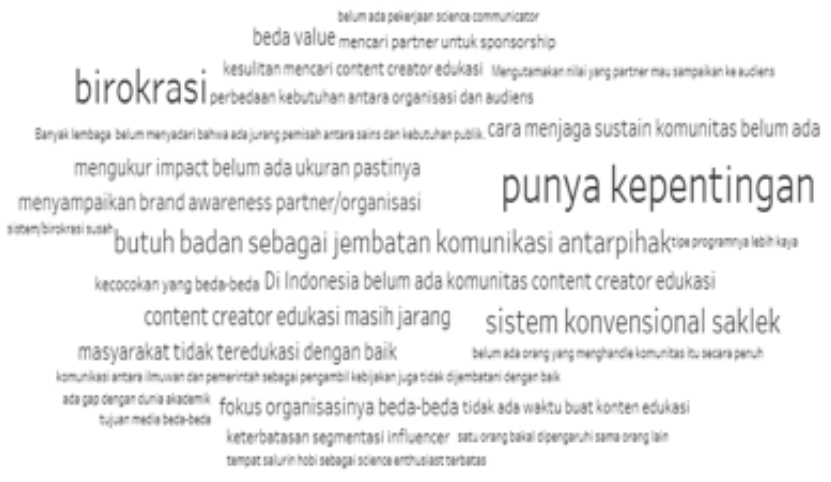

In addition to interests, the second keyword that makes conditions more complex is bureaucracy. There is a difference between media startups and another party with a longer and more complicated bureaucracy. A longer and more complex bureaucracy makes the process of collaboration in composing information hampered.

The editorial process indicates in making the content does not run precisely with the previous planning. The revision process when creating content also becomes slower due to a complicated and long bureaucratic process. The condition is reversed by media startups Kok Bisa, which has a simple bureaucracy in producing information published daily.

Then, rigid conventional systems also become the next significant keyword describing conditions of complexity. The system can be said to be the result of a long and complicated bureaucracy. The system also makes it difficult for actors that equate values to communicate science more simply. For example, they discussed a phenomenon from background to conclusion, about who is entitled to science communication, or referring precisely to the existing curriculum. Sometimes, such a system is ideal but only limited to certain academ- ic spheres. When similar systems are applied for communicating science to non-specialist societies, it becomes complicated to understand. Similarly, it will be a challenge when collaborating with media startups Kok Bisa, who translate the information more simply to understand. The model carried by the media startups Kok Bisa is considered not in line with the ideally rigid conventional system. In the end, the delivery of information becomes complex. Because it follows the system rigidly.

Furthermore, the strategy for overcoming complexity is restructuring. The strategy aims to simplify the flow and process due to the complexity of differences in interests and complex bureaucracy. The most prominent keyword in the word cloud is the akademi edukreator existence and collaboration with various backgrounds, such as the NGO community, government, and private sectors.

Figure 6. Word Cloud of Restructuring

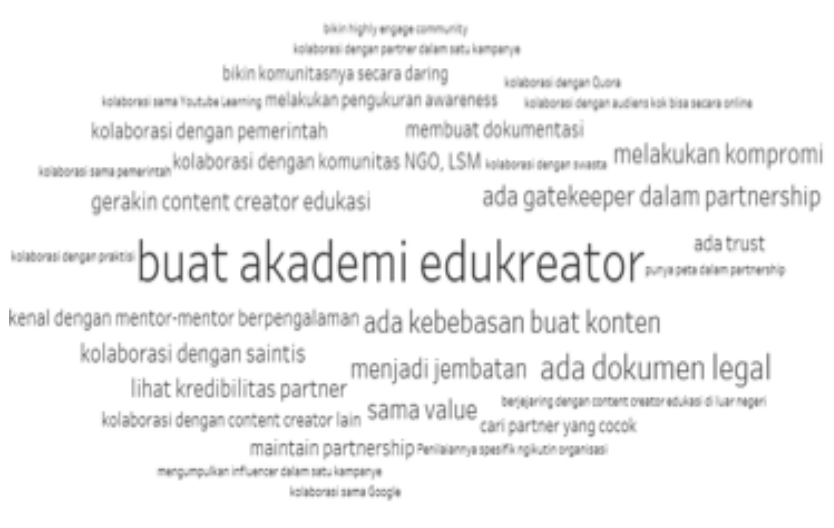

As a connector between many stakeholders, Kok Bisa initiates building a community that encourages creating educational content, called akademi edukreator. Akademi edukreator has been starting to coincide with the COVID-I9 pandemic. The initiation is supported by several agencies such as Youtube Learning, the Ministry of Education and Culture, the Indonesian Institute of Sciences (LIPI), and other content creators. In contrast to conventional systems, the ecosystem of media startups Kok Bisa have a more flexible and straightforward bureaucracy. As a result, Kok Bisa can collaborate and build partnerships with any party with diverse organizational 
backgrounds.

The collaborating agencies have different backgrounds. Some are individual, government, and private sectors. Besides, Kok Bisa has also collaborated with NGOs to create video content and online classes. For example, Kok Bisa with Indika Foundation created infographic classes for the general public about COVID-I9 and created video content to foster Indonesia's tolerance.

In every collaboration with other stakeholders, when Kok Bisa produces content still upholds the value of explaining something simply and entertainingly. Value of simple and entertaining Kok Bisa becomes a consideration for the gatekeeper. So that the collaboration content produced can be accepted readily by the audience.

Internally, there is no complicated and lengthy bureaucracy, as well as when collaborating with other stakeholders. There is a gatekeeper in the partnership to maintain the value owned by Kok Bisa. In this case, actors form a form of restructuring by becoming a bridge that collaborates with many sectors.

The sectors are government, private stakeholders, NGOs, practitioners, scientists, Google, Youtube, and audiences. The complexity due to the many networks is trying to be collected into one hub, i.e the media startups Kok Bisa itself. Through the ability of actors to make several initiations involving many stakeholders. Then, the complexity caused by the many interests' uncertainty is restructured with the use of legal documents, equal value, and trust.

\section{Ambiguity}

Lastly, another challenge that makes the situation complex is ambiguity. Ambiguity refers to the condition of limited knowledge possessed, similar to uncertainty. The difference is the condition of ambiguity does not place something clear. Among other VUCA conditions, ambiguity conditions are among the conditions that cause the most question marks for both media startups and others. There are three most prominent keywords to describe the condition of ambiguity in science com- munication in general, such as differences in perception and conflict with people's beliefs, oversimplification of scientific language, and difficulty translating scientific jargon into common language.

Figure 7. Word Cloud of Ambiguity

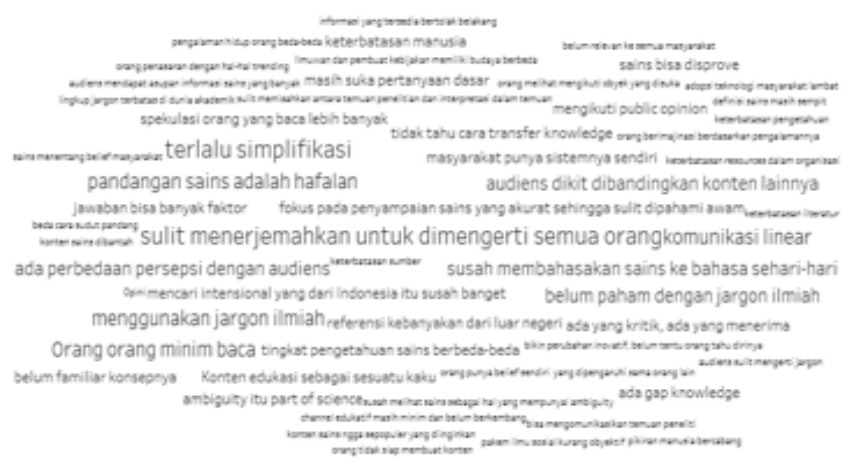

There is a difference in perception with the community because of the gap of knowledge owned by the producer of information with beliefs embraced by the community. Generally, the discussion in science, especially natural sciences, is quite contrary to the belief embraced by most people. Although logically appropriate, the content that smells of science was considered not following the beliefs of society. For example, when Kok Bisa discusses human evolution theory, where there are parts of the body that have decreased function. It is useless. As a result, it is contrary to public belief, where there is a presumption that everything created must be useful. Ambiguous conditions are seen because the belief of society is not in line with the scientific knowledge possessed, so consider science is not a dynamic thing.

Then, another challenge that becomes ambiguous when oversimplification of the study findings. It becomes new information for consumption by the public. The process of simplifying the explanation in question is because a phenomenon can be seen from various points of view so that the process is done because it can only be explained at one momentum.

Furthermore, a potentially ambiguous simplification process is also influenced by the lack of knowledge possessed by the communi- 
ty. As a result, information producers are trying to adapt the information to be enjoyed by the public. Unfortunately, the simplification process is potentially multi-interpretation and ambiguous, which also cannot be separated from the differences in perception and beliefs embraced.

Another keyword is the difficulty of translating the language of scientific jargon into colloquially. The use of jargon becomes an agreement in the scientific world to understand a phenomenon and theory. Unfortunately, the audience does not understand the meaning of the jargon delivered by communicators. In fact, the success of communication when the message to be delivered can be well received by the audience. Nonetheless, the amount of jargon used in each field of science was not understood by people who are not familiar with the scope of the jargon. As a result, the jargon can be interpreted differently because of the limited knowledge of the audience. The impact is that the success of communication will not achieve.

The strategy to overcome ambiguity is experimentation. It is conducted by an actor. Several prominent keywords: provide analogies and create visuals and topics relevant to the audience, the explanations are made simple with common conversational terms, present contrasting narratives, and include popular culture references.

The condition of ambiguity arises from differences in people's beliefs and the difficulty of translating scientific jargon into common conversational terms. Experiments conducted by Kok Bisa also adapt to the Indonesian context, such as providing relevant analogies and humorous elements that are close to the community. The giving of this analogy aims to make it easier for the audience to understand the scientific jargon used in the academic sphere. For example, it describes monosodium glutamate as the term 'micin', which is more popular with the general public.

Moreover, popular culture references are used as a strategy to make 'abstract science content in the shadow of the audience' more relevant. As a result, scientific information can be quickly received by the public as an audience. It is indicated by the popularity of content on Kok Bisa's Youtube and Instagram platforms.

Figure 8. Word Cloud of Experimentation

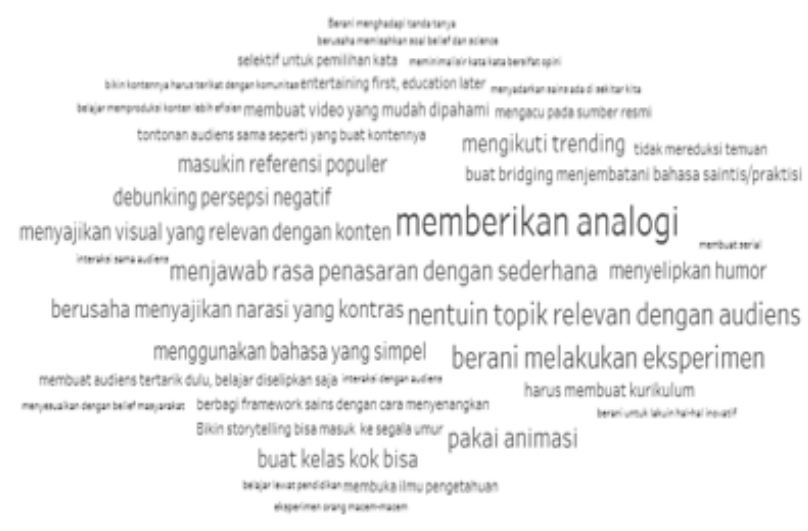

Promoting relevance is the key to every experiment conducted by actors to resolve gaps due to limited knowledge. Kok Bisa also presents a contrasting narrative or helicopter view so that the audience can understand the information in more detail. Then, Kok Bisa lists the sources used so that the audience can learn more about them. Although, differences in perception and belief themselves still color the journey of Kok Bisa in popularizing science in Indonesia. These differences are also inseparable from the definition of science that is still ambiguous. Nonetheless, Kok Bisa also provides an exciting discussion space if there are differences in audience perceptions. In essence, from the experimentation strategy conducted by Kok Bisa, this can be utilized in social transformation which maximizes the ability of actors to make science relevant to their audience and conduct innovative experiments, such as providing analogies, humor, or popular culture references.

From the explanation of the four vulnerable, uncertain, complex, and ambiguous conditions that have a connection with each other, so it becomes complicated challenges for media startup Kok Bisa to develop science communication innovations in Indonesia. As in the COVID-I9 pandemic, it is one of the main conditions that can make them vulnerable. These volatilities have an impact on information uncertainty. Then, the uncertainty 
makes the relationship between actors complex because it has various interests. Complexity also affects being an ambiguous situation because every actor, whether producer or audience, does not have the same agreement in defining things.

Therefore, each strategy overcomes each of these challenges that can be the driving pad for media startups Kok Bisa to transform by utilizing key factors. The key factors such as actor initiation, utilizing social platforms, and knowledge capabilities-building the company's ecosystem's resilience, presenting valid references, restructuring by becoming a bridge for various stakeholders, and experimenting on content into transformative strategies conducted by media startups Kok Bisa.

The strategy can encourage media startups to continue to develop science communication innovations. One of the conditions of uncertainty does not yet have the right strategy, judging by the difficulty of keeping up between the speed of information circulation and accuracy. Similarly, the sustainable science communication ecosystem's vulnerability has not yet been established in Indonesia. Although, there has been an initiation from Kok Bisa to build a community online and create an educational community.

\section{CONCLUSION}

The innovation of science communication conducted by media startup Kok Bisa has become part of the transformation of science communication in Indonesia. Although, the overall ecosystem of science communication and policy as a safe-keeper has not yet been formed. Moreover, the existence of VUCA in the form of vulnerable, uncertain, complex, and ambiguous conditions also color as a challenge faced by media startups Kok Bisa in developing science communication.

As the COVID-I9 pandemic makes conditions vulnerable, rapid momentum makes conditions uncertain, differences in interests and bureaucracy make conditions complex, and difficulty translating scientific jargon into daily conversation terms makes conditions ambiguous. These four challenges show how complex science communication conditions are in Indonesia because the challenges are related to each other. When the condition is vulnerable, it makes the condition uncertain. The uncertainty is inseparable from the complexity of the network formed, coupled with ambiguity. As a result, science communication that media startups have conducted has also become hampered by the VUCA.

Instead of being an obstacle, the VUCA faced by the actor can be a means of performing a more adaptive and realistic social transformation. In science communication, media startup Kok Bisa strives to build agility by forming ecosystems and innovating, making credible information, restructuring by becoming a bridge between stakeholders, and conducting experiments by presenting analogies and creating relevant content. These strategies can be a driver of social transformation because there is an initiation of actors, have qualified knowledge, and use social platforms such as Youtube and Instagram. It shows that relevant stakeholders can use VUCA in developing a more adaptive science communication model in Indonesia.

The qualitative content analysis method depicts phenomena and strategies carried out contextual regarding the framework used and the conditions at hand. In other words, strategies such as media startups Kok Bisa can be applied by similar organizations. Then, some adjustments are needed if the strategy is developed by other stakeholders such as the government, private sector, NGOs, and other institutions. In essence, the study of science communication in Indonesia can be further researched using other methods and taken from different organizations because holistic social transformation itself in science communication has not happened in this time. Nevertheless, it has been done by one of the stakeholders, i.e., media startups.

Theories about VUCA, science communication, and social transformation can identify and analyze how educational content innovation development in social media in Indonesia. The use of the VUCA framework can identify various problems faced by actors in developing 
innovations realistically. Actors can use the concept of science communication to develop educational content based on science, which is readily accepted by the public. Furthermore, from the theory of social transformation, the key factors that drive actors to make social changes can be identified. In conclusion, these three theories suggest that educational content development innovation requires adaptive adjustment according to the capabilities of actors, community culture, and collaboration from various stakeholders. It aims to build citizen science and science-based policymaking in Indonesia.

\section{ACKNOWLEDGEMENT}

This research is funded by Indonesia Lembaga Pengelola Dana Pendidikan (LPDP/Indonesia Endowment Fund for Education).

\section{REFERENCES}

Agostino, D., \& Arnaboldi, M. (2016). A measurement framework for assessing the contribution of social media to public engagement: An empirical analysis on Facebook. Public Management Review, I8(9), I289-I307.

Allgaier, J., Dunwoody, S., Brossard, D., Lo, Y. Y., \& Peters, H. P. (2013). Journalism and social media as means of observing the contexts of science. BioScience, 63(4), $284-287$.

Almobarraz, A. (20I8). Utilization of YouTube as an information resource to support university courses. The Electronic Library.

Apuke, O. D., \& Omar, B. (202I). Fake news and COVID-I9: modelling the predictors of fake news sharing among social media users. Telematics and Informatics, 56, IOI475.

Azzahra, D.A. (2020). Io Channel YouTube Edukasi Indonesia untuk Belajar Online. Retrieved from: https://carisinyal.com/ channel-youtube-edukasi-indonesia/

Barkin, D., \& Sánchez, A. (2020). The communitarian revolutionary subject: new forms of social transformation. Third World Quarterly, 4I(8), I42I-I44I.

Barnes, M. L., Bodin, Ö., Guerrero, A. M., McAllister, R. R., Alexander, S. M., \& Robins, G. (20I7). The social structural foundations of adaptation and transformation in social-ecological systems. Ecology and Society, 22(4).

Bennett, N., \& Lemoine, G. J. (20I4). What a difference a word makes: Understanding threats to performance in a VUCA world. Business Horizons, 57(3), 3II-3I7.

Bilgihan, A., Peng, C., \& Kandampully, J. (20I4). Generation Y's dining information seeking and sharing behavior on social networking sites. International Journal of Contemporary Hospitality Management.

Bowen, G. A. (2009). Document Analysis as A Qualitative Research Method. Qualitative Research Journal 9(2):27-40. DOI:I0.3316/ QRJo902027.

Brossard, D. (2009). Media, scientific journals and science communication: examining the construction of scientific controversies. Public Understanding of Science, I8(3), 258-274.

Bubela, T. (2006). Science communication in transition: genomics hype, public engagement, education and commercialization pressures. Clinical genetics, 70 (5), 445-450.

Bucchi, M., \& Saracino, B. (2016). "Visual Science Literacy" Images and Public Understanding of Science in the Digital Age. Science Communication, 38(6), 8I28ig.

Bucchi, M. (2019). Facing the challenges of science communication 2.0: quality, credibility and expertise. EFSA Journal, I7, eI70702.

Burns, T. W., O'Connor, D. J., \& Stocklmayer, S. M. (2003). Science communication: a contemporary definition. Public understanding of science, I2(2), I83-202.

Cao, W., Zhang, X., Xu, K., \& Wang, Y. (20I6). Modeling online health information- 
seeking behavior in China: The roles of source characteristics, reward assessment, and internet self-efficacy. Health Communication, 3I(9), IIO5-III4.

Castells, M. (20I0). Globalisation, networking, urbanisation: Reflections on the spatial dynamics of the information age. Urban Studies, 47(I3), 2737-2745.

Castles, S. (200I). Studying social transformation. International political science review, 22(I), I3-32.

Chintalapati, N., \& Daruri, V. S. K. (2017). Examining the use of YouTube as a Learning Resource in higher education: Scale development and validation of TAM model. Telematics and Informatics, 34(6), 853-86o.

Claussen, J. E., Cooney, P. B., Defilippi, J. M., Fox, S. G., Glaser, S. M., Hawkes, E., ... \& Midway, S. R. (2013). Science communication in a digital age: Social media and the American Fisheries Society. Fisheries, 38(8), 359-36

Cooke, S. J., Gallagher, A. J., Sopinka, N. M., Nguyen, V. M., Skubel, R. A., Hammerschlag, N., ... \& Danylchuk, A. J. (20I7). Considerations for effective science communication. FACETS, 2, https://doi.org/Io.II39/facets-20I6-0055

Davies, S. R., \& Hara, N. (20I7). Public science in a wired world: How online media are shaping science communication. Science Communication 39(5), 563-568. https:// doi.org/Io.II77/I0755470I7736892

Davies, S. R., Halpern, M., Horst, M., Kirby, D. S., \& Lewenstein, B. (2019). Science stories as culture: experience, identity, narrative and emotion in public communication of science. Journal of Science Communication, I8(5), , AoI. https://doi.org/I0.22323/2.1805020I..

DePaolo, C. A., \& Wilkinson, K. (2014). Get your head into the clouds: Using word clouds for analyzing qualitative assessment data. TechTrends, 58(3), 38-44.

Derakhshan, A., Lee, L., Bhama, P., Barbarite, E., \& Shaye, D. (2019). Assessing the educational quality of 'YouTube'videos for facelifts. American Journal of Otolaryngology, 40(2), 156-159.

DetikInet. (20I8). Luar Biasa! Anak Muda Indonesia dapat Penghargaan dari YouTube. Retrieved from: https://inet. detik.com/cyberlife/d-4I82955/luarbiasa-anak-muda-indonesia-dapatpenghargaan-dari-youtube

Dudo, A. (2015). Scientists, the media, and the public communication of science. Sociology Compass, 9(9), 76I-775.

Duhita, S. (20I7). Kumparan. Belajar Asyik via YouTube dengan "Kok Bisa?". Retrieved from: https://kumparan. com/kumparannews/belajar-asyik-viayoutube-dengan-kok-bisa

Dunwoody, S. (2020). Science journalism and pandemic uncertainty. Media and Communication, 8(2), 47I-474.

Dwivedi, Y. K., Kelly, G., Janssen, M., Rana, N. P., Slade, E. L., \& Clement, M. (2018). Social Media: The good, the bad, and the ugly. Information Systems Frontiers, 20(3), 419-423.

Eise, J. (2019). What institutions can do to improve science communication. Nature.com. Retrieved from: https:// www.nature.com/articles/d4I586-oI903869-7

Fahnestock, J. (2019). Rhetorical Citizenship and the Science of Science Communication. Argumentation, I-I7.

Finkler, W., \& Leon, B. (2019). The power of storytelling and video: a visual rhetoric for science communication. Journal of Science Communication, I8(5), Ao2.

Firdausi, F.A. (2018). Agar Sains Populer, Ilmuwan Perlu Belajar Komunikasi Publik. Tirto ID. Retrieved from: https:// tirto.id/agar-sains-populer-ilmuwanperlu-belajar-komunikasi-publik-c6BW

Fischhoff, B. (20I9). Evaluating science communication. Proceedings of the National Academy of Sciences, II6(I6), 7670-7675. 
Fox, A. K., Nakhata, C., \& Deitz, G. D. (2019). Eat, drink, and create content: a multimethod exploration of visual social media marketing content. International Journal of Advertising, 38(3), 450-470.

Fyfield, M., Henderson, M., \& Phillips, M. (2020). Navigating four billion videos: teacher search strategies and the YouTube algorithm. Learning, Media and Technology, I-I3.

Gagnon, K., \& Sabus, C. (2015). Professionalism in a digital age: opportunities and considerations for using social media in health care. Physical therapy, 95(3), 4064I4.

Guedes, T. S. D. V., Wutrich, F. C. D. S., ShahiniHoaxraj, R., \& Pristina, K. (n.d). The Role of Media Pedagogy in Post-Crisis Societies within a Globalized World.

Guenther, L., Bischoff, J., Löwe, A., Marzinkowski, H., \& Voigt, M. (2019). Scientific evidence and science journalism: Analysing the representation of (un) certainty in German print and online media. Journalism studies, 20(I), 40-59.

Hamid, S., Bukhari, S., Ravana, S. D., Norman, A. A., \& Ijab, M. T. (20I6). Role of social media in information-seeking behaviour of international students. Aslib Journal of Information Management.

Hecker, S., Luckas, M., Brandt, M., Kikillus, H., Marenbach, I., Schiele, B., ... \& Wende, W. (2018). Stories can change the worldcitizen science communication in practice. UCL Press.

Hunter, P. (2016). The communications gap between scientists and public. EMBO reports, I7(II), I5I3-I5I5.

Jeko.(2015). Liputan6com. Kok Bisa?’ Channel YouTube dengan Video Edukatif yang Menghibur. Retrieved from: https:// www.liputan6.com/tekno/read/2321586/ kok-bisa-channel-youtube-denganvideo-edukatif-yang-menghibur
Jones-Jang, S. M., Hart, P. S., Feldman, L., \& Moon, W. K. (2020). Diversifying or reinforcing science communication? Examining the flow of frame contagion across media platforms. Journalism \& Mass Communication Quarterly, 97(I), 98II7.

Jung, I., \& Lee, Y. (2015). YouTube acceptance by university educators and students: a cross-cultural perspective. Innovations in education and teaching international, 52(3), 243-253.

Kandalgaonkar, S. P. (2015). Thinking Skills for Knowledge Workers. Journal of Applied Management-Jidnyasa, 7(2), 32.

Kasih, A.P. (2020). Kompas.com. Akademi Edukreator Buka Kelas Gratis Membuat Konten Edukasi di Youtube. Retrieved from: https://www.kompas.com/edu/ $\mathrm{read} / 2020 / 05 / 06 /$ IoI30927I/akademiedukreator-buka-kelas-gratis-membuatkonten-edukasi-di-youtube?page $=$ all

Kenney, M., Rouvinen, P., \& Zysman, J. (2015). The digital disruption and its societal impacts. Journal of Industry, Competition and Trade, I5(I), I-4.

Khan, M. H. (20I9). Knowledge, skills and organizational capabilities for structural transformation. Structural Change and Economic Dynamics, 48, 42-52.

Kholifah, A.N. (20I8). Viva.co.id. Sempat Ragu Bikin Konten, Channel 'Kok Bisa?' Raih Jutaan Subscriber. Retrieved from: https://www.viva.co.id/digital/ digilife/ro985I7-sempat-ragu-bikinkonten-channel-kok-bisa-raih-jutaansubscriber?page=all\&utm_medium $=$ allpage

Kim, K. S., Sin, S. C. J., \& He, Y. (20I3). Information seeking through social media: impact of user characteristics on social media use. Proceedings of the American Society for Information Science and Technology, 50(I), $\mathrm{I}-4$.

Kocyigit, B. F., Akaltun, M. S., \& Sahin, A. R. (2020). YouTube as a source of information on COVID-I9 and rheumatic disease link. Clinical rheumatology, 39, 
2049-2054

Kok Bisa. (202I). Kok Bisa Company Profile 202I.

Lawi, G.F.K. (2020). Startup Edukasi dan Pelatihan Makin Bersinar di Masa Pandemi. Retrieved from: https://teknologi.bisnis.com/ $\mathrm{read} / 20201002 / 266 / 1299392 / \mathrm{startup}$ edukasi-dan-pelatihan-makin-bersinardi-masa-pandemi

Lee, C. S., Osop, H., Goh, D. H. L., \& Kelni, G. (20I7). Making sense of comments on YouTube educational videos: a selfdirected learning perspective. Online Information Review.

Letaifa, S. B., Edvardsson, B., \& Tronvoll, B. (2016). The role of social platforms in transforming service ecosystems. Journal of Business Research, 69(5), I933-I938.

Lievrouw, L. A. (2010). Social media and the production of knowledge: a return to little science?. Social Epistemology, 24(3), 219-237.

Liu, P. L. (2020). COVID-I9 information seeking on digital media and preventive behaviors: the mediation role of worry. Cyberpsychology, Behavior, and Social Networking, 23(Io), 677-682.

López-Goñi, I., \& Sánchez-Angulo, M. (2018). Social networks as a tool for science communication and public engagement: focus on Twitter. FEMS Microbiology letters, $365(2)$, fnx246.

Mansell, R. (20I0). The life and times of the information society. Prometheus, 28(2), I65-186.

Michalovich, A., \& Hershkovitz, A. (2020). Assessing YouTube science news' credibility: The impact of web-search on the role of video, source, and user attributes. Public Understanding of Science, 29(4), 376-39I.

Moghavvemi, S., Sulaiman, A., Jaafar, N. I., \& Kasem, N. (2018). Social media as a complementary learning tool for teaching and learning: The case of youtube. The International Journal of
Management Education, I6(I), 37-42.

Naeem, M. (2019). Uncovering the role of social media and cross-platform applications as tools for knowledge sharing. VINE Journal of Information and Knowledge Management Systems.

Noonan, M., Richter, G., Durham, L., \& Pierce, E. (2017). Learning and the digital workplace: What? So what? Now what?. Strategic HR Review.

Padian, K. (20I8). Narrative and "anti-narrative" in science: how scientists tell stories, and don't. Integrative and Comparative Biology, 58(6), I224-I234.

Perry, A., Rahim, E., \& Davis, B. (2018). Startup Success Trends in Small Business Beyond Five-Years: A Qualitative Research Study. International Journal of Sustainable Entrepreneurship and Corporate Social Responsibility (IJSECSR), 3(I), I-I6.

Peters, H. P. (2013). Gap between science and media revisited: Scientists as public communicators. Proceedings of the National Academy of Sciences, IIo(Supplement 3), I4IO2-I4IOO.

Picken, J. C. (20I7). From startup to scalable enterprise: Laying the foundation. Business Horizons, 6o(5), 587-595.

Popova, N., Moiseenko, Y., \& Beavitt, T. (20I7). Conformity in modern science: An engine of societal transformation?. Changing Societies \& Personalities, I(3), 237-258.

Qiu, L., Tang, Q., \& Whinston, A. B. (2015). Two formulas for success in social media: Learning and network effects. Journal of Management Information Systems, 32(4), 78-108.

Rapp, A. K., Healy, M. G., Charlton, M. E., Keith, J. N., Rosenbaum, M. E., \& Kapadia, M. R. (2016). YouTube is the most frequently used educational video source for surgical preparation. Journal of surgical education, 73(6), I072-I076.

Redaksi Antara. (2020). Akademi edukreator, wadah bagi kreator tingkatkan kualitas pendidikan. Retrieved from: https:// 
www.antaranews.com/video/I470807/ akademi-edukreator-wadah-bagikreator-tingkatkan-kualitas-pendidikan

Redaksi The Jakarta Post. (2020). 'Akademi Edukreator' initiative aims to inspire teachers, creators in Indonesia. Retrieved from: https://www.thejakartapost.com/ life/2020/05/06/akademi-edukreatorinitiative-aims-to-inspire-teacherscreators-in-indonesia.html

Republika.co.id. (2020). Kemendikbud Akui Konten Pendidikan Terbatas Selama Covid-I9. Retrieved from: https:// republika.co.id/berita/q9ukv2423/ kemendikbud-akui-konten-pendidikanterbatas-selama-covidis

Rundjan, R. (20I8). Penting Untuk Menakar Komunikasi Sains di Indonesia. DW. Retrieved from: https://www.dw.com/ id/penting-untuk-menakar-komunikasisains-di-indonesia/a-42909915

Salmon, R. A., Priestley, R. K., \& Goven, J. (20I7). The reflexive scientist: an approach to transforming public engagement. Journal of Environmental Studies and Sciences, 7(I), 53-68.

Sandi, R. (2020). Lewat Inisiasi 'Akademi Edukreator', Kok Bisa Ajak Kreator Kembangkan Konten Edukasi di Tengah Pandemi. Retrieved from: https://akurat. co/iptek/id-IIo6872-read-lewat-inisiasiakademi-edukreator-kok-bisa-ajakkreator-kembangkan-konten-edukasidi-tengah-pandemi

Schick, A., Hobson, P. R., \& Ibisch, P. L. (20I7). Conservation and sustainable development in a VUCA world: the need for a systemic and ecosystembased approach. Ecosystem Health and Sustainability, 3(4), eoI267.

Schmidt, T. R., \& Lawrence, R. G. (2020). Engaged Journalism and News Work: A Sociotechnical Analysis of Organizational Dynamics and Professional Challenges. Journalism Practice, I4(5), 518-536.

Schreier, M. (2012). Qualitative content analysis in practice. Sage publications.
Segev, E., \& Sharon, A. J. (2017). Temporal patterns of scientific informationseeking on Google and Wikipedia. Public understanding of science, 26(8), 969-985.

Shliakhovchuk, E. (20I9). After cultural literacy: new models of intercultural competency for life and work in a VUCA world. Educational Review, I-22.

Soroya, S. H., Farooq, A., Mahmood, K., Isoaho, J., \& Zara, S. E. (202I). From information seeking to information avoidance: Understanding the health information behavior during a global health crisis. Information Processing \& Management, 58(2), 102440.

Spezi, V. (2016). Is information-seeking behavior of doctoral students changing?: A review of the literature (2010-2015). New review of academic librarianship, 22(I), 78-Io6.

Teece, D., Peteraf, M., \& Leih, S. (2016). Dynamic capabilities and organizational agility: Risk, uncertainty, and strategy in the innovation economy. California management review, 58(4), 13-35.

Tenkasi, R. V. (20I8). Re-visting the past to re-imagine the future of organization development and change. Organ Dev. J, 36(4), 6I-75.

Umeozor, S. N. (2019). Information networking and its application in the digital era with illustration from the University of Port Harcourt Library. International Journal of Knowledge Content Development \& Technology, 9(2), 33-44.

University of People. (n.d). Best Educational YouTube Channels for College Students. Retrieved from: https://www.uopeople. edu/blog/best-educational-youtubechannels-for-college-students/

van der Bles, A. M., van der Linden, S., Freeman, A. L., Mitchell, J., Galvao, A. B., Zaval, L., \& Spiegelhalter, D. J. (20I9). Communicating uncertainty about facts, numbers and science. Royal Society open science, 6(5), I8I870. 
Wankel, C. (2016). Reframing management education with socialmedia. Organization Management Journal, I3(4), 202-213.

We Are Social. (2020). Digital 2020 Indonesia.

Welbourne, D. J., \& Grant, W. J. (2016). Science communication on YouTube: Factors that affect channel and video popularity. Public understanding of science, 25(6), 706$7 \mathrm{I} 8$.

Wicaksono, B.S. (2018). Pentingnya Sains Dunia Digital dalam Hidup Masyarakat. Kompas.com. Retrieved from: https://sains.kompas.com/ read/2018/o 8/0 7/o $70900523 /$ pentingnya-komunikasi-sains-duniadigital-dalam-hidup-masyarakat

Yang, Y., \& Hobbs, J. E. (2020). The power of stories: Narratives and information framing effects in science communication. American Journal of Agricultural Economics.

Zolkepli, I. A., \& Kamarulzaman, Y. (2015). Social media adoption: The role of media needs and innovation characteristics. Computers in Human Behavior, 43, I89209.

Zulfikar,M.(2020). Selama pandemiCOVID-I9, Kemendikbud akui konten pendidikan terbatas. Retrieved from: https://www. antaranews.com/berita/I467459/selamapandemi-covid-r9-kemendikbud-akuikonten-pendidikan-terbatas

\section{AUTHOR BIOGRAPHIES}

Syora Alya Eka Putri graduated from a master program in Department of Sociology, Universitas Indonesia. Expertise in Jakarta Smart City. The member of Research Cluster Economy, Organization, and Society Members

Dr. Ricardi S. Adnan is a lecturer of Economic Sociology, Department of Sociology Universitas Indonesia. Head of Graduate Programme Sociology, Department of Sociology Universitas Indonesia. The member of Research Cluster Economy, Organization, and Society. 